\title{
HUBUNGAN INFEKSI SOIL TRANSMITTED HELMINTHS DENGAN KADAR Hb PADA ANAK SEKOLAH DASAR DI DESA NELAYAN KOTA BENGKULU
}

\author{
Leni Marlina, Halimah, Mualim
}

\author{
Jurusan Analis Kesehatan Poltekkes Kemenkes Bengkulu Jl. Indragiri No.3 Bengkulu \\ Jurusan Analis Kesehatan Poltekkes Kemenkes Bengkulu Jl. Indragiri No.3 Bengkulu \\ Jurusan Kesehatan Lingkungan Poltekkes Kemenkes Bengkulu Jl. Indragiri No.3 Bengkulu
}

\begin{abstract}
Worm disease is a neglected infectious diseases / Neglected Infectious Disease (NIDS), which can lead to declining health, nutrition, intelligence and productivity. Factors that could cause the high incidence of worm disease is sanitation, hygiene, education level, socio-economic, knowledge, attitudes, behavior and geographical conditions. This study aimed to determine the relationship Soil transmitted helminth infections with $\mathrm{Hb}$ levels in elementary school children in the fishing village town of Bengkulu. This study was a cross sectional analytic. Subjects were four primary school pupils in Desa Nelayan of Bengkulu. Large sample of 185 samples. Sampling with simple random sampling technique. Examination of faeces by direct methods. Analysis of the samples by using the test. The result showed no significant association with Hb STH infection $(\mathrm{p}=0.09$ ), no significant relationship with personal hygiene STH infection $(\mathrm{p}=0.89)$, no significant association with the school environment sanitation STH infections $(p=0.34)$ and no significant relationship with the environmental sanitation STH infection $(p=0.70)$ in the elementary school children in Desa Nelayan of Bengkulu. The school have to provide counseling so that maintain the health of the prevention efforts that can reduce STH infections in elementary school children.
\end{abstract}

\begin{abstract}
Abstrak : Helminthiasis merupakan penyakit yang disebabkan oleh cacing atau helminth. Penyakit kecacingan merupakan salah satu penyakit infeksi yang terabaikan/Neglected Infectious Disease (NIDs) yang dapat mengakibatkan menurunnya kondisi kesehatan, gizi, kecerdasan dan produktivitas. Faktor-faktor yang dapat menyebabkan masih tingginya angka kejadian penyakit kecacingan ini adalah sanitasi lingkungan, kebersihan diri, tingkat pendidikan, sosial ekonomi, pengetahuan, sikap, perilaku dan kondisi geografis. Penelitian ini bertujuan untuk menentukan hubungan infeksi Soil Transmitted Helminth dengan kadar Hb pada anak Sekolah Dasar di desa nelayan kota Bengkulu. Penelitian ini merupakan penelitian analitik dengan rancangan cross sectional. Subjek penelitian adalah murid empat Sekolah Dasar di desa nelayan kota Bengkulu. Besar sampel sebanyak 185 sampel. Pengambilan sampel dengan teknik simple random sampling. Pemeriksaan tinja dengan metode langsung. Analisis sampel dengan menggunakan uji t. Hasil penelitian didapatkan tidak ada hubungan yang signifikan infeksi STH dengan kadar $\mathrm{Hb}(\mathrm{p}=0,09)$, tidak ada hubungan yang signifikan personal hygiene dengan infeksi STH $(p=0,89)$, tidak ada hubungan yang signifikan sanitasi lingkungan sekolah dengan infeksi STH $(p=0,34)$ dan tidak ada hubungan yang signifikan sanitasi lingkungan rumah dengan infeksi STH ( $\mathrm{p}=0,70)$ pada anak Sekolah Dasar di desa nelayan kota Bengkulu. Pihak sekolah untuk dapat memberikan penyuluhan sehingga dapat mempertahankan derajat kesehatan dengan usaha pencegahan sehingga dapat menurunkan infeksi STH pada anak Sekolah Dasar.
\end{abstract}

Kata Kunci : STH, kadar Hb, personal higiene, sanitasi lingkungan sekolah dan rumah

Infeksi cacing atau penyakit kecacingan merupakan penyakit yang disebabkan oleh cacing atau Helminth. Penyakit kecacingan merupakan salah satu penyakit infeksi yang sering terabaikan/Neglected Infectious Disease (NIDs) karena tidak menyebabkan kematian secara langsung. Penyakit kecacingan mempengaruhi pemasukan (intake), pencernaan (digestif), penyerapan (absorbsi) dan metabolisme makanan. Secara kumulatif, infeksi cacing dapat menimbulkan kerugian zat gizi berupa kalori dan protein serta kehilangan darah. Selain dapat menghambat perkembangan fisik, kecerdasan dan produktifitas kerja serta dapat menurunkan ketahanan tubuh sehingga mudah terkena penyakit lainnya (Depkes RI, 2006). 
Penyakit kecacingan dapat menurunkan kemampuan belajar dan gangguan fungsi kognitif baik secara langsung maupun tidak langsung sehingga dapat menurunkan sumber daya manusia (Hadidjaja, 1998).

Gejala pada anak-anak yang terinfeksi kecacingan biasanya mengalami lesu, pucat atau anemia, berat badan menurun, tidak bergairah dan bahkan dapat menimbulkan komplikasi yang berat antara lain: kekurangan gizi, anemia penurunan daya tahan fisik sehingga mudah sakit dan dapat mempengaruhi konsentrasi belajar dan penurunan produktifitas anak.

Hasil survei penyakit kecacingan di sekolah dasar di beberapa Propinsi di Indonesia pada tahun 1986-1991 menunjukkan prevalensi yang tinggi sekitar 60\%-80\%, sedangkan untuk semua umur berkisar antara 40\%-60\%. Survei Subdit Diare pada tahun 2002-2003 pada 40 Sekolah Dasar di 10 Propinsi di Indonesia menunjukkan prevalensi berkisar antara 2,2\% - 96,3\% (Depkes, 2006). Prevalensi penyakit kecacingan pada anak sekolah dasar daerah transmigrasi di propinsi Bengkulu meliputi $A$. Lumbricoides $65 \%$, T. Trichiura 55\% dan cacing tambang 22\% (Helmi, 2000). Angka prevalensi penyakit kecacingan anak sekolah dasar Renah Panjang Kecamatan Lubuk Sandi dengan prevalensi $49,9 \%$ yaitu A.lumbricoides $34 \%$ dan T.trichiura 15,9\% (Depkes, 2006). Prevalensi kecacingan di Kecamatan Air Periukan Kabupaten Seluma sebesar 9,2\% (Gazali, 2008).

Kadar hemoglobin mempengaruhi kemampuan darah menghantarkan oksigen yang dibutuhkan untuk metabolisme tubuh yang optimal. Anemia didefinisikan sebagai suatu keadaan kadar hemoglobin $(\mathrm{Hb})$ di dalam darah lebih rendah daripada nilai normal untuk kelompok orang dewasa yang bersangkutan.

Anemia gizi pada anak merupakan masalah sangat penting karena dampak yang ditimbulkan mempengaruhi tingkat kecerdasan dan produktivitas. Di kabupaten Ngawi prevalensi anemia gizi pada anak usia sekolah sebesar 26,3\% (Supri- yadi, 2005). Salah satu penyebab anemia gizi adalah kecacingan. Beberapa studi menemukan, banyak anak anak dan orang dewasa di seluruh dunia anemia kekurangan zat besi. Angka Indonesia juga tercatat tinggi. Pada anak-anak, kekurangan zat besi dapat menyebabkan masalah kognisi serius. Sebuah studi dalam jurnal medik Faediatric Drugs menunjukan, kekurangan besi pada anak batita di kaitkan dengan gangguan perkembangan mental dan psychomotor yang kemungkinan tak bisa di perbaiki. Kekurangan zat besi juga membuat anak kurang bisa konsentrasi dan cepat marah.

Anemia defisiensi zat besi biasanya di sebabkan bila ada pengeluaran yang masif, misalnya karena kecelakaan, darah banyak keluar, atau kekurangan gizi yang berkepanjangan. Selain makro nutri berkurang, bisa menyebabkan anemia defisiensi zat besi. Begitu juga penyerapan yang kurang baik atau absorpsi dan kecacingan pada anak-anak. Anemia defisiensi zat besi berarti kekurangan zat besi, padahal zat besi mineral yang penting untuk membentuk hemoglobin sel darah merah.

Menurut Suhartono (1998) faktorfaktor yang dapat menyebabkan masih tingginya angka kejadian penyakit kecacingan ini adalah kondisi sanitasi lingkungan yang belum memadai, kebersihan diri yang buruk, tingkat pendidikan dan kondisi sosial ekonomi yang rendah, pengetahuan, sikap dan perilaku hidup sehat yang belum membudaya, serta kondisi geografis yang sesuai untuk kehidupan dan perkembangbiakan cacing.

Desa nelayan yang ada di kota Bengkulu merupakan daerah dengan kondisi geografis yang sesuai untuk kehidupan dan perkembangbiakan cacing. Tanah yang baik untuk pertumbuhan adalah tanah gembur (pasir, humus). Di desa nelayan kota Bengkulu terdapat $4 \mathrm{SD} /$ sederajat yaitu SDN 47 di Kampung Piri Berkas, SDN 11 di Kampung Cina, SDN 57 di Pasar Baru, MI Al Islam di Sumber jaya Teluk Sepang Pulau Baii. 
Metoda yang paling sederhana untuk memeriksa kecacingan adalah menggunakan feces yang dicampur dengan larutan iosin/ lugo dan diperiksa dibawah mikroskop. Tujuan penelitian untuk mengetahui prevalensi kecacingan dan menentukan hubungan infeksi STH dengan kadar $\mathrm{Hb}$ pada anak Sekolah Dasar di desa nelayan kota Bengkulu.

\section{BAHAN DAN CARA KERJA}

Jenis penelitian ini merupakan penelitian analitik dengan menggunakan rancangan cross sectional. Sampel dalam penelitian ini adalah jumlah anak sekolah dasar yang mewakili dari populasi. Pengambilan sampel simple random sampling. Besarnya sampel sebesar 46 anak setiap SD (4 SD) yang berjumlah 185 anak ditentukan berdasarkan prevalensi kecacingan. (Leme- show, 1997). Data primer di peroleh dari hasil pemeriksaan sampel tinja dengan metode langsung di laboratorium terpadu Poltekkes Kemenkes Bengkulu dengan cara mengambil dengan pipet 1 tetes Iodin /Lugol/eosin dan diteteskan di atas gelas benda, dengan lidi, tinja diambil (1-2 mg) pada gelas benda dan dihancurkan di atas larutan Iodin/Lugol/eosin, menutup dengan gelas penutup kemudian diperiksa di bawah mikroskop dengan pembesaran $10 \mathrm{x}$ dilanjutkan dengan $40 \mathrm{x}$. Analisa data dengan menggunakan uji t.

\section{HASIL}

Analisis univariat untuk melihat nilai mean, median, SD, minimal dan maksimal serta distribusi frekuensi variabel independen, dapat dilihat pada tabel di bawah ini.

Tabel 1. Distribusi Frekuensi Kadar Hb, Personal Hiegiene, Sanitasi Lingkungan Sekolah dan Rumah

\begin{tabular}{lcccc}
\hline \multicolumn{1}{c}{ Variabel } & Mean & SD & Minimal-maksimal & $95 \%$ CI \\
\hline Kadar Hb & 9,87 & 0,99 & $8-13$ & $9,72-10,01$ \\
Personal Higiene & 7,22 & 0,62 & $6-8$ & $7,13-7,31$ \\
Sanitasi Lingkungan Sekolah & 7,74 & 1,80 & $6-10$ & $7,47-8,00$ \\
Sanitasi lingkungan Rumah & 12,50 & 1,62 & $8-15$ & $12,27-12,74$ \\
\hline
\end{tabular}

Tabel 1 menunjukkan kadar $\mathrm{Hb}$ ratarata sebesar 9,87 $\mathrm{gr} / \mathrm{dl}$, personal higiene rata-rata 7,22, sanitasi lingkungan sekolah rata-rata 7,74 dan untuk sanitasi lingkungan rumah rata-rata 12,50 pada anak sekolah dasar di desa nelayan kota Bengkulu.

Sedangkan hasil distribusi frekuensi infeksi soil Transmitted Helmint menunjukkan bahwa infeksi STH positif sebesar 17 $(9,19 \%)$.

Tabel 3. Distribusi Rata-Rata Kadar Hb, Personal Higiene, Sanitasi Lingkungan Sekolah dan Rumah Antara Infeksi STH Negatif Dan STH Positif Pada Anak Sekolah Dasar di Desa Nelayan Kota Bengkulu

\begin{tabular}{lccc}
\hline \multicolumn{1}{c}{ Variabel } & STH & Mean & P \\
\hline Kadar $\mathrm{Hb}$ & Negatif & 9,91 & 0,09 \\
Personal Higiene & Positif & 9,48 & 0,89 \\
& Negatif & 7,21 & \\
Sanitasi Lingkungan Sekolah & Positif & 7,24 & 0,34 \\
\multirow{2}{*}{ Sanitasi lingkungan Rumah } & Negatif & 7,77 & 0,70 \\
& Positif & 7,35 & 0,79 \\
\hline
\end{tabular}

Analisis ini dilakukan untuk mengetahui perbedaan nilai rata-rata antara infeksi STH positif dan negatif dengan menggunakan uji beda mean atau uji t. Hasil penelitian diperoleh tidak ada perbedaan ratarata yang signifikan antara infeksi STH ne- gatif dan infeksi STH positif dengan kadar $\mathrm{Hb}(\mathrm{p}=0,09)$. Nilai $\mathrm{p}>0,05$ berarti tidak ada hubungan yang signifikan antara infeksi STH dengan kadar Hb. Tidak ada perbedaan rata-rata personal higiene yang signifikan antara infeksi STH negatif dan infek- 
si STH positif $(\mathrm{p}=0,89)$. Nilai $\mathrm{p}>0,05$ berarti tidak ada hubungan yang signifikan antara personal higiene dengan infeksi STH. Tidak ada perbedaan rata-rata sanitasi lingkungan sekolah yang signifikan antara infeksi STH negatif dan infeksi STH positif $(\mathrm{p}=0,34)$. Nilai $\mathrm{p}>0,05$ berarti tidak ada hubungan yang signifikan antara sanitasi lingkungan sekolah dengan infeksi STH. Tidak ada perbedaan rata-rata sanitasi lingkungan rumah yang signifikan antara infeksi STH negatif dan infeksi STH positif $(p=0,70)$. Nilai $p>0,05$ berarti tidak ada hubungan yang signifikan antara sanitasi lingkungan rumah dengan infeksi STH. Hasil Model Summary, didapatkan nilai $\mathrm{R}$ square sebesar $4,0 \%$. Hal ini menunjukkan pengertian bahwa kadar $\mathrm{Hb}$ pada anak sekolah dasar di desa nelayan kota Bengkulu dipengaruhi sebesar $4,0 \%$ oleh variabel personal higiene, sanitasi lingkungan sekolah, sanitasi lingkungan rumah dan infeksi STH.

\section{PEMBAHASAN}

\section{Hubungan Infeksi STH dengan Kadar Hb}

Hasil uji beda mean untuk infeksi STH didapatkan hasil tidak ada hubungan yang signifikan dengan kadar $\mathrm{Hb}$ pada anak SD di desa nelayan Kota Bengkulu. Hasil ini berbeda dengan penelitian Sukek-si dan Andri tahun 2000 menyatakan ada perbedaan infeksi STH positif dan negatif dengan kadar Hb. Sejalan dengan penelitian Wirakusumah (1999) yang menyatakan ada hubungan infeksi kecacingan dengan anemia. Anak usia sekolah mempunyai aktivitas fisik yang tinggi dan masih dalam proses belajar. Dengan demikian untuk mendapatkan kondisi yang prima guna meningkatkan prestasi belajarnya diperlukan kadar hemoglobin yang normal (Depkes RI, 1999).

Kecacingan pada anak sekolah dasar berpengaruh pada perubahan kadar $\mathrm{Hb}$ disebabkan oleh cacing A. lumbricoides dapat terjadi malabsorbsi. Gangguan absorbsi zat besi dapat terjadi, padahal zat besi sangat diperlukan dalam pembentukan sel darah merah (Gandahusada et al., 2006). Penyakit cacing tambang yang menahun dapat menyebabkan anemia terutama oleh A. duodenale, karena setiap hari dapat menghisap darah lebih kurang 0,08-0,34 cc, walaupun tidak menyebabkan kematian tetapi daya tahan tubuh berkurang dan prestasi di sekolah dapat menurun (Gandahusada et al., 2006). Hasil penelitian ini menunjukan tidak ada hubungan infeksi STH dengan kadar $\mathrm{Hb}$, hal ini kemungkinan penurunan kadar $\mathrm{Hb}$ disebabkan asupan nutrisi yang mengandung zat besi yang kurang.

\section{Hubungan Personal Higiene dengan Infeksi STH}

Hasil uji beda mean untuk personal higiene didapatkan hasil tidak ada perbedaan rata-rata personal higiene yang signifikan antara infeksi STH negatif dan infeksi STH positif pada anak SD di desa nelayan Kota Bengkulu. Sesuai dengan penelitian yang dilakukan oleh Gazali (2008) yang menyatakan ada hubungan personal higiene dengan infeksi STH, semakin baik personal higiene anak SD maka semakin rendah peluang terkena infeksi STH. Hal ini juga tidak sesuai dengan penelitian oleh Depkes (2005) yang menyatakan ada hubungan bermakna personal higiene dengan kejadian kecacingan. Sejalan dengan penelitian Curtale et al. (1998) yang disetasi oleh Wachidanijah (2002) menyatakan prevalensi kecacingan rendah didapat pada anak yang mempunyai personal hygiene baik.

Menurut Adi Sasongko, kunci pemberantasan kecacingan adalah memperbaiki higiene dan sanitasi lingkungan. Misalnya, tidak menyiram jalanan dengan air got. Sebaiknya, bilas sayur mentah dengan air mengalir atau mencelupkannya beberapa detik ke dalam air mendidih. Juga tidak jajan di sembarang tempat, apalagi jajanan yang terbuka. Biasakan pula mencuci tangan sebelum makan, bukan hanya sesudah makan. Dengan begitu, rantai pe- 
nularan cacingan bisa diputus (Depkes, 2006).

\section{Hubungan Sanitasi Lingkungan Sekolah dengan Infeksi STH}

Hasil uji beda mean untuk sanitasi lingkungan sekolah didapatkan hasil tidak ada perbedaan rata-rata sanitasi lingkungan sekolah yang signifikan antara infeksi STH negatif dan infeksi STH positif pada anak SD di desa nelayan Kota Bengkulu. Sejalan dengan penelitian Sumanto tahun 2010 menunjukan bahwa tidak ada hubungan sanitasi sekolah dengan kejadian kecacingan. Hal ini dimungkinkan dari hasil pengamatan dari beberapa SD halaman sekolah sudah memakai paving blok/semen walaupun masih ada yang halaman berupa tanah/pasir.

Keadaan sanitasi lingkungan sekolah juga dapat berperan aktif dalam menyebabkan kecacingan. Berdasarkan pengamatan pada beberapa sekolah di desa nelayan Kota Bengkulu, sebagian besar sanitasi lingkungan sekolah masih rendah. Hal ini dapat terlihat dengan tidak tersedianya sabun untuk cuci tangan, masih ada anak tidak memakai alas kaki ketika waktu istirahat, tidak tersedianya kantin sekolah yang sehat dan tidak tersedianya jamban yang memenuhi syarat kesehatan. Masih ditemukan beberapa sekolah yang jamban tidak tersedia sumber air bersih dan sabun.

Lingkungan fisik sekolah meliputi ketersediaan jamban, kebersihan halaman sekolah, pengawasan warung atau tempat jajan sekolah, kebersihan perorangan anak sekolah dan pemeriksaan fisik anak sekolah serta kunjungan ke rumah anak sekolah. Kegiatan-kegiatan tersebut di sekolah sudah tercakup dalam program Usaha Kesehatan Sekolah (UKS). Program pemberantasan dan pencegahan infeksi kecacingan secara otomatis telah dimasukkan dalam kegiatan UKS tersebut (Santoso, 1994).

Lingkungan fisik sekolah secara tidak langsung juga mempunyai sumbangan terhadap terjadinya infeksi kecacingan walau- pun tidak cukup besar. Ini dibuktikan dalam penelitian yang dilakukan oleh Wachidanijah (2002) masih dijumpai beberapa anak SD tidak memakai alas kaki ketika sekolah, karena keadaan tanah becek dan rumah berada di lereng pegunungan sehingga anak selalu kontak dengan tanah di lingkungan sekolah. Tanah liat dan kelembaban tinggi merupakan beberapa faktor yang mendukung berkembangnya telur Ascaris lumbricoides menjadi bentuk infektif (Gandahusada dkk, 2006).

\section{Hubungan Sanitasi Lingkungan Rumah dengan Infeksi STH}

Hasil uji beda mean untuk sanitasi lingkungan rumah didapatkan hasil tidak ada perbedaan rata-rata sanitasi lingkungan rumah yang signifikan antara infeksi STH negatif dan infeksi STH positif pada anak SD di desa nelayan Kota Bengkulu. Hal ini sesuai dengan penelitian Gazali tahun 2008 menunjukan bahwa sanitasi lingkungan rumah anak SD tidak ada hubungan bermakna dengan infeksi STH. Berbeda dengan penelitian yang dilakukan Sumanto tahun 2010 yang menyatakan ada hubungan sanitasi rumah dengan infeksi kecacingan. Faktor lingkungan rumah yang masih banyak tanah juga merupakan sarana atau media yang baik untuk berkembangbiaknya cacing (Wardhianna, 1997). Tanah merupakan media yang sangat baik bagi perkembangbiakan cacing. Penularan infeksi Soil Transmitted Helminths ini dapat terjadi karena faktor tanah yang pantas untuk perkembangbiakan cacing, terkontaminasinya tanah dengan feses dan terkontaminasinya tanah dengan makanan, minuman dan kulit manusia.

Hasil tabel Model Summary, ditampilkan nilai $\mathrm{R}$ square sebesar $4,0 \%$. Hal ini menunjukkan pengertian bahwa kadar $\mathrm{Hb}$ pada anak dipengaruhi sebesar 4,0\% oleh variabel infeksi STH, personal hygiene, sanitasi lingkungan sekolah dan rumah. Menurut Gazali (2008) higiene perorangan dan lingkungan merupakan faktor yang paling berperan dalam terjadi penyakit keca- 
cingan. Faktor lingkungan antara lain lingkungan fisik. Lingkungan fisik yang mempengaruhi infeksi penularan infeksi kecacingan yaitu struktur tanah dan suhu. (Gandahusada et al., 2006).

\section{KESIMPULAN}

Berdasarkan hasil penelitian ini maka dapat disimpulkan bahwa prevalensi STH sebesar 9,19\%, tidak ada hubungan yang signifikan $(\mathrm{p}=0,09)$ antara infeksi STH dengan kadar $\mathrm{Hb}$, tidak ada hubungan yang signifikan $(\mathrm{p}=0,89)$ antara personal hiegiene dengan infeksi STH, tidak ada hubu-

\section{DAFTAR KEPUSTAKAAN}

Arikunto, Suharsimi, 2002. Prosedur Penelitian Suatu Pendekatan Praktik. Rineka Cipta, Jakarta.

Depkes RI, 1998. Pedoman Program Pemberantasan Penyakit Kecacingan. Departemen Kesehatan RI, Dirjen PPM \& PLP, Jakarta.

Gandahusada, S., Illahude, D.H., Pribadi, W., 2006. Parasitologi Kedokteran. Balai Penerbit Fakultas Kedokteran Universitas Indonesia, Jakarta.

Gazali, M., 2008. Hubungan higiene perseorangan anak Sekolah Dasar dan kondisi kesehatan lingkungan rumah dengan kejadian penyakit kecacingan di Kecamatan Air Periukan Kabupaten Seluma Propinsi Bengkulu. Thesis, Program Pascasarjana Universitas Gadjah Mada, Yogyakarta.

Hadidjaja, P., 1998. The effect of intervention metthods on nutrisional status and cognitive function of primary school children infected with Ascaris lumbricoides. Am. J Trop.Med.Hyg.,

Helmi, D., 2000. Penyakit Cacing di Unit Transmigrasi Propinsi Bengkulu pada Anak Sekolah Dasar, Dimuat dalam http://digilib.unmer.ac.id/go.php.

Notoadmodjo, S., 2003. Pendidikan dan Perilaku Kesehatan. PT. Rineka Cipta, Jakarta. ngan yang signifikan $(\mathrm{p}=0,34)$ antara sanitasi lingkungan sekolah dengan infeksi STH, tidak ada hubungan yang signifikan $(\mathrm{p}=0,70)$ antara sanitasi lingkungan rumah dengan infeksi STH pada anak Sekolah Dasar di desa nelayan Kota Bengkulu.

Disarankan kepada pihak sekolah perlu meningkatkan usaha promosi kesehatan dengan cara melakukan penyuluhan kesehatan khususnya tentang kecacingan serta usaha pencegahan dengan cara membiasakan budaya hidup bersih sehingga diharapkan angka kecacingan tidak ditemukan lagi pada anak sekolah dasar.

Sandjaja, B., 2007. Parasitologi Kedokteran, Helminthologi Kedokteran Buku-2. Prestasi Pustaka. Jakarta.

Suhartono, 1998. Faktor-Faktor yang Berhubungan dengan kejadian dan Intensitas Kecacingan pada Murid Sekolah Dasar di Kabupaten Karanganyar Jawa Tengah Tahun 1995. Media Medika Indonesia Wachidanijah, 2002. Pengetahuan, sikap dan perilaku anak serta lingkungan rumah dan sekolah dengan kejadian infeksi kecacingan anak Sekolah Dasar (Studi di Kecamatan Prembun Kabupaten Kebumen). Thesis, Program Pascasarjana Universitas Gadjah Mada, Yogyakarta.

Wachinadijah, Sutomo, A.H., Padawati, 2002. Pengetahuan, Sikap dan Perilaku Anak serta Lingkungan Rumah dan Sekolah dengan kejadian Infeksi Kecacingan anak Sekolah Dasar, Berita kedokteran Masyarakat, XVIII (9)

Wardhianna, S., 1997. Peranan ibu rumah tangga dalam meningkatkan kesehatan lingkungan sebagai upaya memutus rantai penularan penyakit cacing pada anak. Thesis, Program Pascasarjana Universitas Gadjah Mada, Yogyakarta. 